\title{
Michael Domjan and the functional significance of the conditional response
}

\author{
Shepard Siegel ${ }^{1}$
}

Accepted: 15 October 2021 / Published online: 16 December 2021

(C) The Psychonomic Society, Inc. 2021

I am very pleased to introduce this special issue of Learning \& Behavior honoring Michael Domjan, since Michael started his research career with me. As a recent $\mathrm{PhD}$, and a new faculty member at McMaster University, I was extraordinarily fortunate to have him as one of my first graduate students. I came to McMaster in 1968, and Michael enrolled in the McMaster graduate program in 1969.

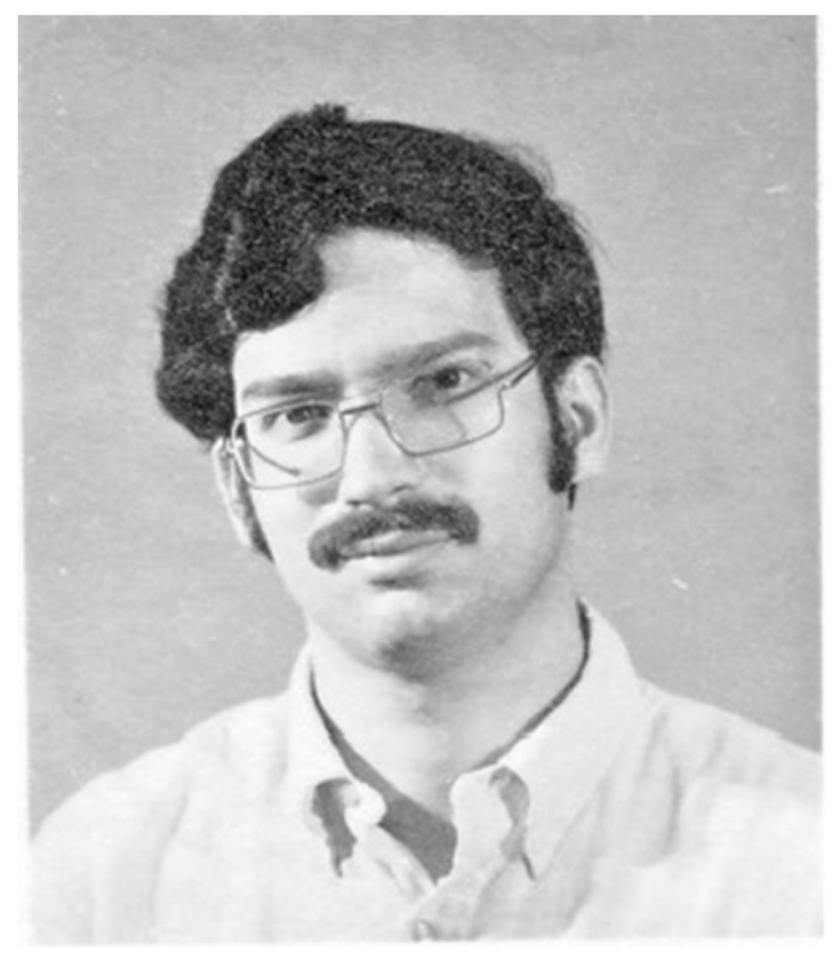

Michael Domjan in 1969

Shepard Siegel

siegel@mcmaster.ca

1 Department of Psychology, McMaster University, Hamilton, Ontario L8S 4K1, Canada
Although it has been about half a century since he did his graduate work, my memories of him as a graduate student are still vivid.

As a new graduate student, Michael was already a sophisticated researcher. Although we jointly published a few papers (mostly concerned with the inhibitory effects of backward conditioning), it was clear that his primary interests lay elsewhere. He was enthusiastic about the then-recent research on biological constraints on learning, specifically taste-aversion learning. I was mostly concerned with other associative phenomena and lacked Michael's appreciation of the importance of taste-aversion learning, and especially the Garcia and Koelling (1966) "bright-noisy-water" experiment that demonstrated the selective association effect. Early on, Michael recognized that these findings were likely to change our thinking about associations, and even then was sophisticated enough to pursue relevant research with very little supervision from me. His thesis, completed in 1973, consists of an amazing series of 12 experiments. He investigated the role of ingestion in taste-aversion and odor-aversion learning. He demonstrated that taste without ingestion would result in a taste aversion, but ingestion facilitates the aversion behavior. He invented techniques to get a rat to taste, but not consume, flavors, and presented a complete package to make his points. He did all this pretty much independently.

He sailed through his $\mathrm{PhD}$ oral exam and assumed a faculty position at the University of Texas, where he has remained. He has more than fulfilled expectation of professional success based on his graduate student career. He continued to make major contributions to the selectiveassociation effect in his new job, and recently summarized his extensive contributions to that topic (Domjan, 2015). But taste-aversion learning was only the start of an amazing research career. Flavor-illness associations are only one example of the interaction of learning and evolutionary principles. He has consistently demonstrated that Pavlovian conditioning researchers who used arbitrary conditional stimuli (CSs) and unconditional stimuli (USs), and measured 
conditional responses by twitches in the CS-US interval, were missing the point: "In many cases, moreover, the most important outcome of conditioning is not the emergence of a new response to the CS but the capacity of the CS to change how the individual responds to the US" (Domjan, 2021, p. 87).

He demonstrated this in many ways, but his major work was an extensive series of investigations of the role of Pavlovian conditioning in the sexual behavior of the Japanese quail (Coturnix japonica). He noted: "The past 100 years of Pavlovian conditioning has told researchers much about how the conditioned response develops . . . but little about why it develops" (with Hollis et al., 1997, providing a notable exception; Matthews et al., 2007, p. 758). He rectified this oversight in many papers, but perhaps most clearly in Matthews et al. (2007). Michael and colleagues demonstrated that when two male quails sequentially mated with females, they were equally likely to sire offspring (paternity was assessed by DNA fingerprinting). However, when copulatory opportunity was signaled by a contextual CS for one of the two males, that male sired 2.5 times as many offspring as the male that did not have a signal prior to mating. This work was extended by Domjan et al. (2012), clearly demonstrating that "by increasing fertilization rates, sexual conditioning can alter genetic transmission across generations and shape evolutionary change (Domjan et al., 2012, p. 1). This is a fitting riposte to Michael's receipt, in 1988, of Senator William Proxmire's "Golden Fleece" award for his federally funded research on the sexual behavior of quail.

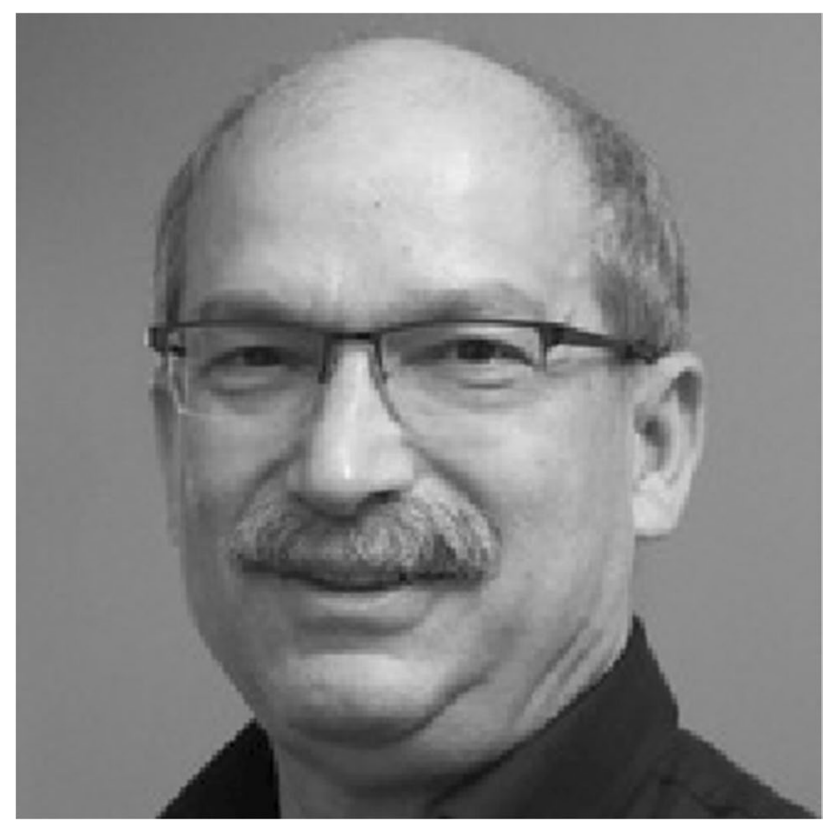

Michael Domjan Today
Recently, Michael has engaged in a second act. Before studying psychology, he was a student at the Juilliard School of Music, where he was well on the path to becoming a professional concert musician. He decided to study psychology instead, but not before becoming proficient on the viola. After a 35-year hiatus, he is revisiting his musical roots. Michael is integrating his first love, music, with experimental psychology. He has created the "Tertis/Pavlov Project," named after Lionel Tertis (a prominent viola player) and Ivan Pavlov. The project consists of a series of lectures about the relationship between music and psychology. He has put the project together in a series of videos (which can be found at https://www.youtube.com/channel/UCt_DMROXrGYSJ KEDqd5K1iw). Michael's stunning viola solos are a highlight of the lectures.

It would be a heroic job to summarize Michael's contributions, presented in about 150 research publications. He has consistently conducted creative and convincing research that demonstrated the functional and ecological importance of conditioning. As illustrated by the Tertis/Pavlov project, his work also is entertaining.

\section{References}

Domjan, M. (2015). The Garcia-Koelling selective association effect: A historical and personal perspective. International Journal of Comparative Psychology, 28. http://escholarship.org/uc/item/ $5 \mathrm{sx} 993 \mathrm{rm}$

Domjan, M. (2021). What's wrong with this picture? Just about everything. APS Observer, 34, 86-87. https://www.psychologicalsc ience.org/observer/revisiting-pavlovian-conditioning

Domjan, M., Mahometa, M. J., \& Matthews, R. N. (2012). Learning in intimate connections: Conditioned fertility and its role in sexual competition. Socioaffective Neuroscience and Psychology, 2(1), Article 17333. https://doi.org/10.3402/snp.v2i0.17333

Garcia, J., \& Koelling, R. A. (1966). Relation of cue to consequence in avoidance learning. Psychonomic Science, 4(3), 123-124. https:// doi.org/10.3758/BF03342209

Hollis, K. L., Pharr, V. L., Dumas, M. J., Britton, G. B., \& Field, J. (1997). Classical conditioning provides paternity advantage for territorial male blue gouramis (Trichogaster trichopterus). Journal of Comparative Psychology, 111(3), 219-225. https://doi.org/ 10.1037/0735-7036.111.3.219

Matthews, R. N., Domjan, M., Ramsay, M., \& Crews, D. (2007). Learning effects on sperm competition and reproductive fitness. Psychological Science, 18(9), 758-762. https://doi.org/10.1111/j. 1467-9280.2007.01974.x

Publisher's note Springer Nature remains neutral with regard to jurisdictional claims in published maps and institutional affiliations. 